more usual course and went to Germany to continue academic research, though he rejoined his old colleague later to continue an association which lasted throughout Sheppard's life. Mees turned to industry for reasons which he afterwards stated to be political. The son of a Wesleyan minister, he was a Fabian who realized that an equal sharing of wealth, while effectively depriving the rich, would do little to benefit the poor. What was needed was a general increase in the standard of living, and this he believed could be achieved only by the application of science to industry. An experience from the Wratten and Wainwright days can now be seen to epitomize what he considered should be the objectives of industrial research. Mr. Wratten had told him that plate prices were being cut, profits were diminishing and that he must devote his energies to reducing their manufacturing cost. Mees completely ignored these instructions. The blue-sensitive plates of the day were being bathed by the user in solutions of dyes to make them sensitive to longer wave-lengths. He found out how to incorporate this step during manufacture and proceeded to market outstandingly good panchromatic plates at a premium price with great benefit to the Company's profits. Throughout his subsequent career he was always aiming to open up new markets with new products; others could worry about holding existing markets. In another way these early years in industry set the pattern of what was to come, in that despite his many preoccupations with commercial problems, he found time to publish several scientific papers of importance.

He had made himself so indispensable to Wratten and Wainwright's that when, in 1912, George Eastman wanted his services in order to found a research laboratory, he had to purchase the Company. His subsequent career with the Eastman Kodak Co. continued until he retired in 1955, seeing him appointed a director in 1923 and vice-president in charge of research in 1934. He became internationally recognized as a pioneer in industrial research and a great exponent of it. The reputation of his laboratory in Rochester, New York, grew by bis insistence on high standards and on the publication of the results of research. The decision whether to publish or not was based on the principle that results of value to science ought to be published. This was in line with his belief that industry should repay its debt to pure science, in accordance with which belief he undertook to supply special-and unprofitable-plates to astronomers and started the manufacture of Eastman organic chemicals when the United States was cut off from German supplies during the First World War--a service still valued by organic chemists everywhere. He established research laboratories in the Company's subsidiaries in England and in France and was a frequent visitor to Europe.

Mees's influence on the commercial success of the Company was equally great, and he was largely responsible for such outstanding contributions as the introduction of amateur cinematography and for the popularization of colour photography in all its forms. Of his personal work, apart from many scientific papers, must be mentioned one of the earliest books on the organization of industrial research, published in 1920, which was brought up to date much later by the publication in collaboration with John A. Leermakers of "The Organization of Industrial Scientific Research". His greatest contribution to scientific literature was the "Theory of the Photographic
Process" (1954), which had its origins in the book published in collaboration with Sheppard based on their research theses in 1907 which became known simply as "Sheppard and Mees". Recognition of his work was made plain by his receiving from almost every scientific body connected with photography their highest awards, by his election to the fellowship of the Royal Society (1939) and to membership of the U.S. National Academy of Sciences on becoming an American citizen in 1950.

Perhaps Mees's outstanding characteristic was his insistence on the importance of facts and his ability to analyse their implications. It was for this reason that in debate he could be a devastating opponent, but if it could be shown that the facts were against him he cheerfully accepted, not defeat, but the new circumstances. Mees usually dominated any group in which he found himself, mainly by the clarity with which he saw any problem (and the solution to it) and the consequent forcefulness with which he could express himself. He once gave the advice to one of his men, who was writing a book: "If you don' $t$ know for certain, don't say it ; if you must say it, be dogmatic !" He was widely read, an authority on many subjects, ranging from astronomy to the history of ancient Egypt, having as a central theme the growth of science and technology through the ages. This interest led to the publication in 1946 of "The Path of Science", written in conjunction with John R. Baker. He was a brilliant lecturer, as those who remember his Royal Institution Christmas lectures in 1935 will know, and a stimulating conversationalist. His views on the organization of industrial research were widely sought by other directors of research and by industrialists. They can well be summed up as insistence on the importance of the individual. He had no use for the idea that research had to become a team effort, and he believed that the youngest of men could do worth-while research if given the opportunity, as he had indeed proved in his own case. He surrounded himself by many brilliant individualists, gave them the freedom such men require, and regarded his job as the protection of these men from the direction of others rather than the direction of their work by himself. He asked the Company to judge by the end-results. It had no regrets.

Mees married in 1909 Alice Crisp (she died in 1954), by whom he had a son and a daughter.

E. R. Davies

\section{Dr. R. C. Farmer, O.B.E.}

The death of Dr. R. C. Farmer on July 30 at the age of eighty-two has removed one of the great pioneers from the world of military explosives. He was well known not only for his contributions to the defence of the State but also for his publications, which appeared over a number of years in scientific journals. It is remarkable that his last three papers were printed in the Journal of the Chemical Society when he was within a few weeks of eighty-two. He married, in 1908, Maud Mary, daughter of Mr. T. T. Sharpe, of Liverpool, and had two sons and one daughter, all of whom have taken up scientific work.

Robert Crosbie Farmer was born on November 30, 1877, in Liverpool, where he received his early education and later graduated with first-class honours at the University. With the aid of scholarships he studied at Würzburg under Hantzsch and Röntgen, and was awarded the Ph.D. (summa cum laude) for 
his work on the tautomerism of hydrazones and oximes. After a short spell as analyst in a paint works, he entered the University of Birmingham with a Priestley scholarship and worked on the use of liquid nitric peroxide as a solvent for organic compounds. He also developed a new way for measuring hydrolytic dissociation (partition method). Afterwards he was appointed lecturer and demonstrator and was awarded the degree of M.Sc. (Birmingham and Victoria).

In 1902 he became principal assistant to the late Dr. O.J. Silberrad at the Experimental Establishment of the War Office Explosives Committee (later Research Department, Woolwich), of which Lord Rayleigh was president and Sir William Crookes a member. His earliest work was on the mechanism of the decomposition of nitrocellulose and on cordite Mk. I, which had ignited spontaneously in several magazines in India. This work was embodied in his thesis for a D.Se. (Liverpool). When Dr. Silberrad left in 1906, the vacant post was offered to Dr. Farmer, but serious ill-health at that time prevented his acceptance and Dr. (later Sir) Robert Robertson was appointed. During the ensuing years he continued his work on the chemical stability of explosives and developed the vacuum stability test for high explosives, a test which is now regarded of first importance in considering their suitability for Service use. When War started in 1914, he devised a process for the manufacture of trinitrotoluene which was used on the largest scale in Government factories and by several private firms. Early in 1915 he was transferred to the Department of Explosives Supply and became chief chemical adviser to the director general, Lord Moulton. In this capacity he was responsible for guidance to manufacturers and safety of processes, several of which he improved. He had control of extra-mural research in this field at the universities and was a member of many committees, including those on Munitions Inventions and Nitrogen Products.

At the conclusion of the War in 1918 he was made O.B.E. and received a Russian decoration, the Order of St. Anne. He left the Government service, forfeiting all rights to pension, and became a director of W. J. Bush and Co., manufacturers of fine chemicals. In 1922 he accepted an invitation to return to the Research Department as deputy director of explosives research and later became chemical adviser. In these capacities he was largely responsible for organizing researches and dealing with a multitude of technical problems arising in the Fighting Services. He represented the Department on a number of committees, including those on Adhesives and Forest Products under the Department of Scientific and Industrial Research, and for some years was a member of the Council of the Institute of Chemistry. On retirement he continued research work at King's College, London, up to his last years.

Dr. Farmer was of a lovable disposition and sacrificed all considerations of self to duty. $\mathrm{He}_{\Theta}$ had abundant wit and his speeches on lighter occasions were masterpieces. His recreation was walking. No one can be more indebted to him for his generously given help through strenuous years than myself.

GODFrey RotTer

\section{NEWS and VIEWS}

\section{Bacteriology at University College Hospital Medical School: Prof. Wilson Smith, F.R.S.}

Prof. Wilson Smith is retiring from the chair of bacteriology at University College Hospital Medical School, a position he has occupied since 1946. Prof. Smith is a Manchester graduate, having qualified in 1923. In 1927 he went to work at the National Institute for Medical Research at Hampstead and soon came to the fore as a contributor to knowledge about viruses, particularly vaccinia and herpes. In 1933, with P. P. Laidlaw and C. H. Andrewes, he demon. strated that influenza virus would infect ferrets, a discovery which opened the way to a laboratory investigation of the disease; and in the following years these three workers laid the foundations of present-day knowledge of influenza in its laboratory aspects; they soon found that the virus would infect mice, could be grown in fertile eggs and in tissue culture and could be studied by means of various serological tests. In 1939 Wilson Smith was appointed to the chair of bacteriology at the University of Sheffield, but returned to London in 1946 to the chair which he is now vacating. With

various collaborators he has continued to work on influenza, particularly its serological aspects, and on poliomyelitis. His contributions have not only been to virology, however, but also to bacteriology. $\mathrm{He}_{\boldsymbol{\theta}}$ was elected to the fellowship of the Royal Society in 1949 and has twice served on its council. He delivered the Society's Leeuwenhoek Lecture in 1957 on "Virus host Cell Relationships".

\section{Messrs. Macmillan announce that, as from January I, 1961, the subscription price for Nature will be 68 . 8s. per annum and pro rata. The price of single issues remains $2 \mathrm{~s}$. $6 \mathrm{~d}$.}

Prof. G. Belyavin

Prof. Wilson Smith is succeeded in the chair of bacteriology in University College Hospital Medical School by Dr. George Belyavin, who is at present senior lecturer in that department. Dr. Belyavin was educated at St. Paul's School and the Westminster Hospital, from which he graduated M.B., B.S. in 1943. He was awarded the M.D. in 1960. During 1944 46 he acted as resident pathologist to the Westminster Hospital, and from 1946 until 1949 he was a member of the Department of Biological Standards of the National Institute for Medical Research, Hampstead. Since 1949 he has been continuously at University College Hospital Medical School. Dr. Belyavin has had two main research interests-immunology and virology which, as his 